\title{
PENGARUH PEMBERIAN AIR PERASAN JERUK NIPIS (Citrus aurantifolia) TERHADAP JUMLAH PIGMEN MELANIN KULIT MENCIT (Mus musculus) YANG DIPAPARKAN SINAR MATAHARI
}

\author{
${ }^{1}$ Anggun R.P. Layuck \\ ${ }^{2}$ Poppy M. Lintong \\ ${ }^{2}$ Lily L. Loho
}

\author{
${ }^{1}$ Kandidat Skripsi Fakultas Kedokteran Universitas Sam Ratulangi Manado \\ ${ }^{2}$ Bagian Patologi Anatomi Fakultas Kedokteran \\ Universitas Sam Ratulangi Manado \\ Email: anggun.layuck@yahoo.com
}

\begin{abstract}
Over exposure of light can increase skin pigmentation. The aim of this study is to know the effect of lime and light exposure to the amount of melanin in mice's skin. This is an experimental research and used mices as the subject research, which was randomly divided into 5 mice of control group and 15 mices of treatment group. Group A (K-) were given pellets for 20 days, Group B $(\mathrm{K}+)$ were given pellets and light exposure for 1 hour in 20 days, Group $\mathrm{C}$ were given pellets, smeared by lime on the back, then exposed to the light for 1 hour in 20 days, Group D were given pellets and exposed to light for 1 hour in 20 days then smeared by lime the next 10 days. The results showed that light exposure increases melanin pigment in group B compared to group A. For group C and group D, the amount of melanin pigment is less than group B. Conclusions: Lime can reduce the amount of melanin pigment in mice's skin that had been exposed to the light.
\end{abstract}

Keywords: melanin pigment, sunlight, lime

\begin{abstract}
Abstrak: Paparan berlebihan terhadap sinar matahari dapat meningkatkan pigmentasi kulit. Penelitian ini bertujuan untuk mengetahui pengaruh pemberian jeruk nipis dan pemaparan sinar matahari terhadap jumlah pigmen melanin kulit mencit. Metode penelitian yang digunakan adalah metode eksperimental dengan subjek penelitian menggunakan mencit yang dibagi atas 5 ekor kontrol dan 15 ekor perlakuan. Kelompok A (K-) diberikan pelet selama 20 hari, Kelompok B (K+) diberikan pelet dan sinar matahari selama 1 jam dalam waktu 20 hari, kelompok $\mathrm{C}$ diberikan pelet, diolesi jeruk nipis di bagian punggung, lalu dipaparkan sinar matahari selama 1 jam dalam waktu 20 hari, kelompok D diberikan pelet, dipaparkan sinar matahari selama 1 jam dalam waktu 20 hari lalu diolesi jeruk nipis 10 hari berikutnya. Hasilnya : paparan sinar matahari menunjukkan peningkatan pigmen melanin pada kelompok $\mathrm{B}(\mathrm{K}+)$ dibandingkan dengan kelompok A (K-). Sedangkan pada kelompok C dan kelompok D menunjukkan jumlah pigmen melanin yang lebih berkurang dibandingkan kelompok B. Simpulan: Pemberian jeruk nipis menurunkan jumlah pigmen melanin kulit mencit yang dipaparkan sinar matahari.
\end{abstract}

Kata kunci : pigmen melanin, sinar matahari, air perasan jeruk nipis

Paparan berlebihan pada sinar matahari dapat memberikan dampak negatif bagi kesehatan kulit manusia. Sinar matahari mengandung sinar ultraviolet $\mathrm{A}$, sinar ultraviolet B, dan sinar ultraviolet C. Sinar ultraviolet B memiliki keaktifan biologis tertinggi. $^{1}$

Dampak negatif yang ditimbulkan akibat paparan sinar matahari berlebihan terhadap kulit dalam fase akut antara lain 
seperti kerusakan DNA, eritema, mutasi, pigmentasi, dan imunosupresi. Paparan sinar matahari dalam jangka waktu yang lama mengakibatkan terjadinya penuaan dini pada kulit serta kanker kulit. Paparan berlebihan sinar matahari menyebabkan peningkatkan pigmentasi pada kulit. Melanin yang berfungsi sebagai pelindung kulit diproduksi lebih banyak oleh melanosit seiring dengan besarnya intensitas paparan oleh sinar matahari. Semakin intens paparan sinar matahari terhadap kulit, semakin banyak pula melanin yang akan diproduksi melanosit. ${ }^{2}$

Jeruk nipis (Citrus aurantifolia) merupakan tanaman yang memiliki banyak khasiat.Khasiat jeruk nipis diantaranya dapat membantu penyembuhan berbagai macam penyakit sepeti disentri, sembelit, ambeien, batuk, haid tidak teratur, suara serak, dan batu ginjal.Khasiat jeruk nipis tidak hanya sebatas bisa mengatasi berbagai macam penyakit namun juga ternyata dapat mencerahkan dan menghaluskan kulit.Dampak positif tersebut disebabkan karena kandungan vitamin C dalam jeruk nipis yang mempunyai sifat mudah teroksidasi sehingga berperan sebagai reduktor pada sintesis melanin yang banyak membutuhkan oksigen serta mampu mengubah bentuk melanin oksidasi berwarna gelap menjadi melanin tereduksi yang berwarna agak pucat. Jeruk nipis juga berperan sebagai tirosinase inhibitor.,

Kulit adalah organ tubuh yang terletak paling luar sekaligus merupakan organ terbesar pada tubuh manusia. ${ }^{5}$ Kulit terdiri dari tiga lapisan utama yaitu lapisan epidermis, lapisan dermis, dan lapisan subkutis. Di lapisan epidermis terdiri atas stratum korneom, stratum lusidum, stratum granulosum, stratum spinosum dan stratum basale. Di stratum basale terdapat sel-sel melanosit yang berfungsi memproduksi melanin. ${ }^{6}$ Di dalam melanosit diproduksi dua subtipe melanin, yaitu eumelanin dan pheomelanin. Keduanya adalah derivat dari asam amino tirosin dan disintesis dari oksidasi tirosin oleh enzim tirosinase dan juga berperan dalam regulasi homestasis epidermal. ${ }^{7}$ Pada orang yang kulitnya berwarna gelap, melanosit memproduksi lebih banyak melanin, melanosomnya berbentuk lebih besar daripada mereka yang memilki warna kulit yang terang. ${ }^{8}$ Menghitamnya kulit (tanning) akibat paparan sinar matahari dipengaruhi oleh adanya peningkatan aktivitas enzim tirosinase dalam melanogenesis. $^{8}$

Tujuan penelitian ini ialah untuk mengetahui dampak pemberian air perasan jeruk nipis dan pemaparan sinar matahari terhadap jumlah pigmen melanin kulit mencit.

\section{METODE PENELITIAN}

Penelitian ini dilakukan sejak bulan September 2014 sampai bulan Januari 2015 di Laboratorium Patologi Anatomi Fakultas Kedokteran Universitas Sam Ratulangi dengan menggunakan desain penelitian eksperimental. Subjek penelitian yang digunakan adalah 20 ekor mencit yang terdiri dari kelompok kontrol 5 ekor dan kelompok perlakuan 15 ekor.Mencit dalam penelitian ini dibagi atas 4 kelompok, dimana kelompok A Kelompok A (kelompok kontrol negatif). Hanya diberikan makanan berupa pelet selama 20 hari kemudian dibiopsi kulitnya pada hari ke-21.Kelompok B (kelompok perlakuan I) yang diberikan paparan sinar matahari selama 1 jam dalam 20 hari dan kemudian dibiopsi kulitnya pada hari ke-21. Kelompok C (kelompok perlakuan 2) yang diberikan olesan jeruk nipis di punggung kulit mencit kemudian dipaparkan sinar matahari selama 1 jam dalam 20 hari dan dibiopsi kulinya pada hari ke-21. Kelompok D (kelompok perlakuan 3) yang dipaparkan sinar matahari selama 20 hari kemudian dioleskan jeruk nipis di bagian punggung hari ke-21 sampai hari ke-30 dan dibiopsi kulitnya pada hari ke-31. Jumlah pigmen melanin yang akan dihitung adalah pigmen melanin yang terlihat per satu lapangan pandang, pembesaran mikroskop 100x10, dengan interpretasi dibagi 3 kategori : sedikit ( $<40$ pigmen melanin), sedang (40-80 pigmen melanin), banyak ( $>80$ pigmen melanin). 


\section{Alat dan Bahan}

Alat yang digunakan adalah loyang plastic, kawat kasa, pellet, dan botol air, pisau, timbangan gram, jarum, gunting, pisau bedah, objek gelas, wadah tempat fiksasi, mikroskop cahaya, dan kamera mikroskop digital. Sementara bahan yang digunakan adalah jeruk nipis formalin, aseton, xylol (pewarnaan HE) dan juga pewarnaan Fontana Masson.

\section{Prosedur Penelitian \\ Pemeliharaan mencit}

Dipelihara mencit sebanyak 20 ekor dalam keadaan sehat di dalam kandang mencitselama 3 hari tanpa perlakuan sebagai proses penyesuaian agar tidak stress. Mencit diberi makan dalam bentuk pelet dan minum dari botol air.

\section{Penentuan lama pajanan sinar matahari}

Berdasarkan penelitian yang dilakukan, menggelapnya kulit akibat pajanan sinar matahari secara terusmenerus maksimal selama kurang lebih 3 minggu. Pajanan selama 1 jam pada pukul 11.00-12.00 pun diyakini mampu memperlihatkan perubahan pada stratum basal kulit dengan adanya peningkatan jumlah melanin yang diproduksi melanosit.

\section{Pemberian jeruk nipis}

Jeruk nipis yang diberikan adalah sebanyak 100gram (3 buah jeruk nipis ukuran sama). Punggung mencit dicukur seluas $4 \times 4 \mathrm{~cm}$.eruk nipis diberikan dengan cara diiris daging buahnya, diambil perasan airnya, lalu dengan kuas dioleskan di bagian punggung $4 \times 4 \mathrm{~cm} 30$ menit sebelum dipaparkan sinar matahari.

\section{HASIL PENELITIAN Kelompok A}

Gambaran mikroskopik kulit mencit dengan pewarnaan Fontana Masson menunjukkan butir-butir pigmen melanin berwarna coklat kehitaman dan jika dihitung jumlahnya kurang dari 40 butir pigmen.

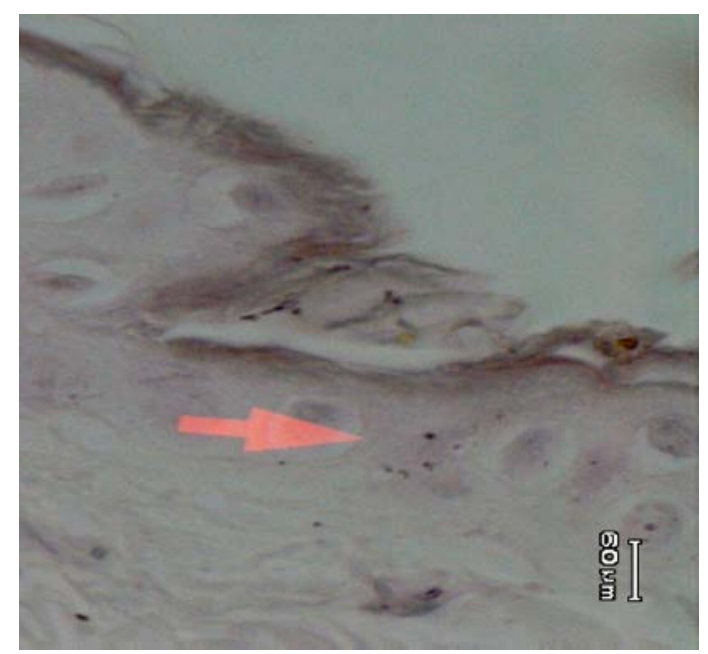

Gambar 1.Tampak epidermis normal dan tampak butir-butir pigmen melanin pada epidermis kurang dari 40 butir (lihat panah merah).

\section{Kelompok B}

Gambaran mikroskopik kulit mencit menggunakan pewarnaan Fontana Masson kelompok ini, terlihat jelas butir-butir pigmen melanin yang jumlahnya lebih dari 80 butir.

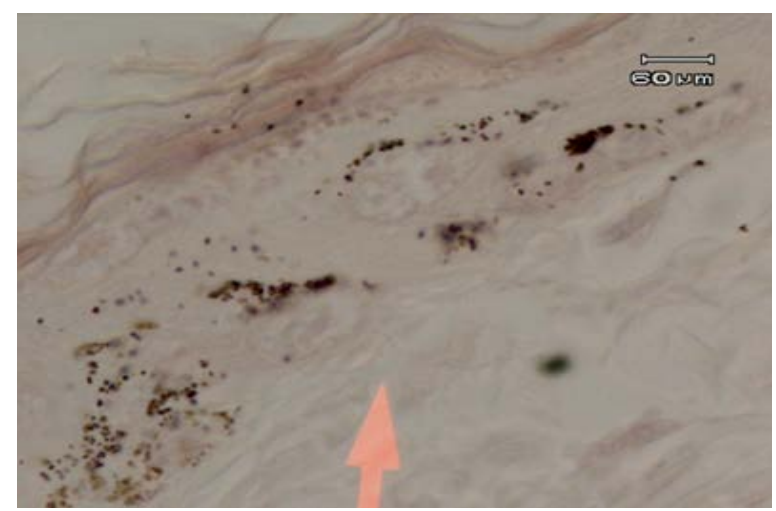

Gambar 2. Tampak butir-butir pigmen melanin warna coklat kehitaman terdapat pada lapisan epidermis juga pada lapisan keratin (panah merah).

\section{Kelompok C}

Gambaran mikroskopik kulit mencit dengan pewarnaan Fontana Masson, tampak butir-butir pigmen melanin yang berwarna coklat kehitaman berjumlah di antara 40-80 butir. 


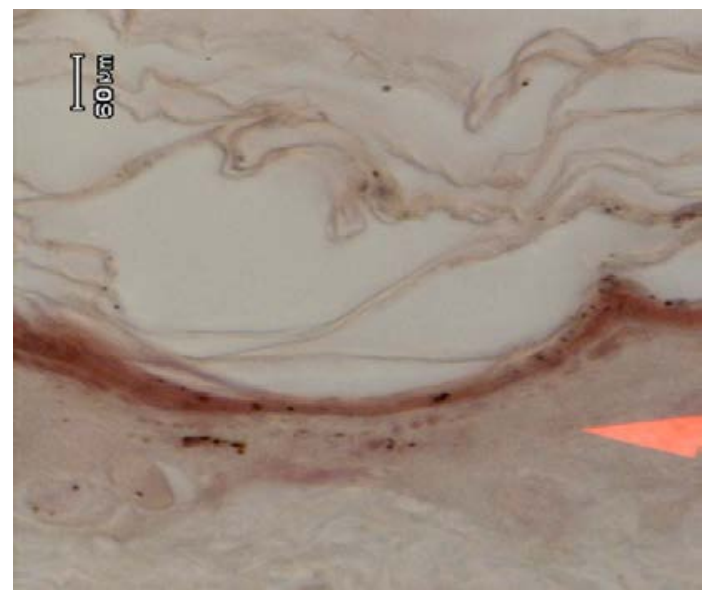

Gambar 3.Tampak butir-butir pigmen melanin warna coklat kehitaman pada epidermis dan naik sampai pada lapisan keratin (panah merah).

\section{Kelompok D}

Gambaran mikroskopik kulit mencit dengan pewarnaan Fontana Masson menunjukkan jumlah pigmen melanin yang kurang dari 40.Beberapa pigmen melanin tampak tersebar sampai ke lapisan tanduk di stratum korneum.

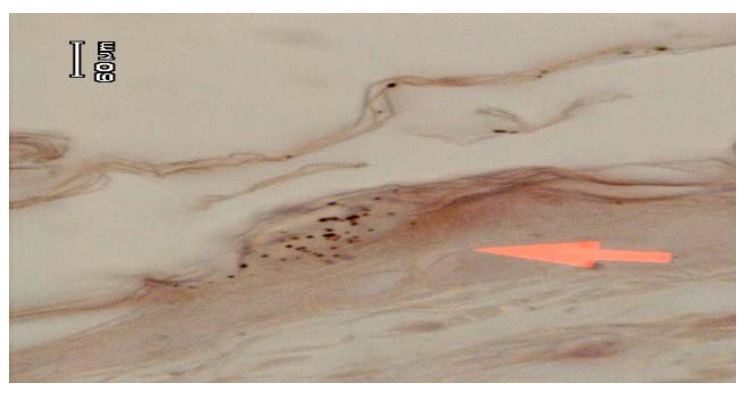

Gambar 4.Gambaran mikroskopik kulit mencit kelompok perlakuan D, yaitu mencit yang diberi pelet standar dan diberi paparan sinar matahari 1 jam selama 20 hari setelah itu dioleskan jeruk nipis di punggung mencit selama 10 hari.Tampak butir-butir pigmen melanin warna coklat kehitaman pada epidermis sampai lapisan keratin (panah merah).

\section{BAHASAN}

Pada penelitian yang dilakukan ini, telah terbukti bahwa kulit punggung mencit yang diberi paparan sinar matahari mengalami peningkatan jumlah melanin, yaitu lebih dari 80 butir pigmen jumlahnya (dikategorikan banyak). Hal ini dipengaruhi oleh kerja enzim tirosinase yang meningkat sehingga turut meningkatkan pula aktivitas melanosit sehingga meningkatkan produksi pigmen melanin. Melanin yang diproduksi melanosit berfungsi melindungi kulit terhadap sengatan sinar matahari sehingga melanin akan semakin meningkat jumlahnya apabila intensitas paparan terhadap sinar matahari juga meningkat. ${ }^{\mathbf{8}}$

Tabel 1. Jumlah pigmen melanin

\begin{tabular}{cccc}
\hline Kelompok & $\begin{array}{c}\text { Jumlah } \\
\text { Pigmen } \\
\text { Melanin }\end{array}$ & Klasifikasi & Kategori \\
\hline A & 21 & $<40$ & \\
B & 96 & $>80$ & Sedikit \\
C & 49 & $40-80$ & Sedang \\
D & 34 & $<40$ & Sedikit \\
\hline
\end{tabular}

Pemberian jeruk nipis secara lokal pada kulit punggung mencit dengan cara diolesi sebelum dipaparkan dengan sinar matahari terbukti mengurangi jumlah butir pigmen melanin, hal ini terlihat pada mencit kelompok perlakuan C. Pada kelompok perlakuan ini jumlah melanin menurun dari kategori banyak (kelompok perlakuan B) menjadi kategori sedang dengan jumlah 40-50 butir pigmen melanin. Terjadinya pengurangan jumlah pigmen melanin ini karena peranan jeruk nipis sebagai tirosinase inhibitor. Tirosinase adalah monooksigenase yang mengandung $\mathrm{Cu}$ dimana enzim ini berperan sebagai katalisator pada reaksi ohidroksilasi monofenol menjadi bentuk difenol (monofenolase) dan oksidase difenol menjadi o-kuinon (difenolase). Tirosinase memainkan peranan penting dalam pembentukan melanin selama proses melanogenesis karena tirosinase mampu menghidroksilasi L-tirosin (monofenol) menjadi L-DOPA (difenol) dan mengoksidasi L-DOPA menjadi dopaquinon (senyawa kuinon). Dopaquinon yang terbentuk akan bereaksi spontan membentuk dopakrom yang kemudian menjadi melanin. Dengan adanya jeruk 
nipis, semua proses ini dapat dihambat. Jeruk nipis juga menghambat produksi melanin dengan menurunkan o-kuinon. ${ }^{9}$

Pada mencit yang dipaparkan sinar matahari selama 20 hari kemudian diolesi jeruk nipis selama 10 hari berturut-turut menunjukkan produksi pigmen melanin yang semakin menurun, jumlah pigmen melanin berubah dari kategori sedang (4080 butir pigmen) menjadi sedikit ( $<40$ butir pigmen). Kandungan vitamin $\mathrm{C}$ yang tinggi dalam jeruk nipis mempunyai sifat mudah teroksidasi sehingga berperan sebagai antioksidan atau reduktor pada sintesis melanin yang banyak membutuhkan oksigen.Selain itu, vitamin C dapat mengubah bentuk melanin oksidasi yang berwarna gelap (eumelanin) menjadi melanin tereduksi yang berwarna agak pucat (pheomelanin).Vitamin $\mathrm{C}$ juga dapat menghambat perubahan dopa menjadi dopakuinon (proses pigmentasi kulit) sehingga mencegah pembentukan melanin. Vitamin $C$ dan flavonoid yang terkandung dalam jeruk nipis mencerah-kan kulit dengan cara memperbarui sel serta mempercepat proses pergantian sel. ${ }^{3,4}$ Produksi melanin menurun seperti pada kelompok D ini juga bisa karena proses fisiologi kulit setelah dihentikan dengan paparan sinar matahari selain karena peranan jeruk nipis sendiri.Oleh karena itu diperlukan penelitian lebih lanjut.

\section{SIMPULAN}

Pemaparan sinar matahari meningkatkan jumlah pigmen melanin kulit mencit dan pemberian jeruk nipis menunjukkan penurunan jumlah pigmen melanin kulit mencit yang dipaparkan sinar matahari.

\section{SARAN}

1. Perlu dipertimbangkan waktu pemaparan sinar matahari lebih baik tidak dilakukan di bulan-bulan dengan musim penghujan.

2. Perlu dipertimbangkan untuk hewan coba karena mencit sangat tidak tahan dengan stress yang diberikan (paparan sinar matahari) dan mudah mati.

3. Perlu dilakukan paparan sinar matahari dan pemberian jeruk nipis lebih lama untuk mendapatkan hasil yang lebih akurat dan maksimal.

\section{UCAPAN TERIMA KASIH}

Ucapan terima kasih disampaikan kepada dr.Grace Kapantow, Sp.KK dan dr. Meilany Durry, M.Kes, Sp.PA selaku penguji skripsi yang telah memberikan kritikan dan saran, serta semua pihak, baik secara langsung maupun tidak langsung, yang telah memberikan ide dan gagasan kepada penulis dalam menyelesaikan artikel ini.

\section{DAFTAR PUSTAKA}

1. Makiyah SN, Iszamriach $R$, Novariyandi A. Paparan Ultraviolet C Meningkatkan Diameter Pulpa Alba Limpa dan Indeks Mitotik Epidermis Kulit Mencit. Jurnal Kedokteran Brawijaya. 2014;28:1.

2. Brenner M, Hearing V. The Protective Role of Melanin Against UV Damage in Human Skin. NIH Public Access. 2008;84(3):539-49.

3. Karinah A. Jeruk Nipis. Edisi ke-1. Surabaya: Stomata;2012.

4. Thiele J, Dreher F, Pocker L. Antioxidant Defense System in Skin. Dalam : Elsner P, Maicbach HI (eds) Cosmeutical, Drug VS Cosmetic. Marcel Dekker Inc.New York, Basel 2000: 145-150

5. Price S. Gangguan Sistem Dermatologi. Dalam: dr.Huriawati Hartanto, dr.Natalia Susi, dr. Pita Wulansari, dr.Dewi Mahanani, editor. Patofisiologi,Konsep Klinis,ProsesProses penyakit. Edisi ke-6. Jakarta; 2012. hal. 1416-17.

6. Djuanda A. Ilmu Penyakit Kulit dan Kelamin. Edisi ke-6. Jakarta: Balai Penerbit Fakultas Kedokteran Universitas Indonesia; 2011.

7. Park HY, Pongpudpunth M, Lee J, Yaar M. Biology of melanocyte: Melanin Biosynthesis. Dalam: Fitzpatrick's TB, Wolff Klaus, editor. Dermatology in general 
medicine. Edisi ke-9. New York:

McGraw-Hill; 2008. hal.602.

8. Baumann L. Skin Types. In: Leslie Baumann, Sogol Saghari, Edmund Weisberg, editor. Cosmetic Dermatology. Edisi ke-2. New York: McGraw-Hill; 2009. hal.98.

9. Smit N, Vicanova J, Pavel S. The Hunt of Natural Skin Whitening Agents. International Journal of Molecular Sciences. 2009;10:5326-49. 